\title{
Developing Module of the Inventive Problem Solving Theory in Problem-Based Learning
}

\author{
Che Wan Razak, C.W.H.S, Yee, M. H, Tee T. K, Kok, B. C, Mohamad, M. M
}

\begin{abstract}
Problem-solving is an important aspect to be applied to students in preparation for challenges in learning or everyday life. Therefore, the appropriate approach that needs to be exposed to students is problem-based learning (PBM). PBM is a learning tool that exposes real problems using systematic problem-solving. In this regard, to enhance the students' knowledge to be more creative and innovative, there is a theory that can help students to solve problems in PBM. This theory is known as the Theory of Inventive Problem Solving (TRIZ), which can be integrated into PBM as a guide to problem-solving more effectively. The purpose of this study is to develop the integration of TRIZ in PBM module by analyzing the feedback of format, content and usability of the module from lecturers and students. This study uses a quantitative approach involving five lecturers and 15 students. The data were analyzed descriptively and presented in the form of frequency and percentages. The findings show that five lecturers are 100\%, and 15 students are 98.17\% agreed with the module format. While $97.14 \%$ of lecturers and $91.8 \%$ of students agreed with the contents of the module developed. For module usability, there are 100\% lecturers, and $96.2 \%$ agreed that the developed module could be used. In conclusion, this module is suitable for students to solve inventive problems in PBM which provided by lecturers.
\end{abstract}

Keywords : Theory of Inventive Problem Solving (TRIZ), Problem Based Learning

\section{INTRODUCTION}

In an effort towards the nation development, the changes made in the educational pattern provide students with diverse skills and knowledge. Ref [1] stated include skills in problem-solving in learning. Problem solving skill is one the important elements and skills required in the 21st Century Skills (Educational Technology Division, 2012). Problem solving skill is an essential aspect required by students for preparing themselves in facing challenging life. Problem solving skill helps students to generate creative thinking and innovative thinking skills too students can develop creative thinking and innovative thinking skills to generate thoughtful ideas.

Nowadays, the government and industrial requires

Revised Manuscript Received on 14 September, 2019.

Che Wan Razak, C. W. H. S, Faculty of Technical and Vocational, UTHM, Batu Pahat, Malaysia

Yee, M. H. Department of Engineering Education, UTHM, Batu Pahat, Malaysia

Tee T, K, Department of Technical Education, UTHM, Batu Pahat, Malaysia

Kok, B. C. Department of Electrical Engineering, UTHM, Batu Pahat, Malaysia

Mohamad, M. M. Department of Engineering Education, UTHM, Batu Pahat, Malaysia employess with fully prepared with employability skills included problem solving skills. (Noriah, 2006). Therefore, students should be exposed with the appropriate approaching problem-based learning (PBM). According to Ref [2], PBM is a learning tool that use systematics problem solving process by using real problems. With the problem-solving skills in this PBM, it can encourage students to participate in the classroom actively. Furthermore, students can apply their knowledge to solve problems in finding solutions to their learning problems [3]. Burden and Byrd (1994) have stated that PBM is student-centred learning approach included discussion, collaboration and even more interactive problem-solving.

In this regard, to further enhance the students' knowledge to be more creative and innovative, a theory that can help students to solve problems in PBM. Theory is can be used in PBM as a troubleshooting guide is known as Theory of Inventive Problem Solving (TRIZ) or creative problem-solving theory that introduced by. Russian engineer, Genrich Altshuller. TRIZ is a theory that uses structured, and systematic problem-solving approaches and ideas can be generated more creatively and innovatively[4]. TRIZ is a more systematic and -problem solving process, TRIZ has been integrated into PBMTRIZ can bridging the gap in the steps implemented in PBM, so that students can solve more specific problems. Therefore, the integration of TRIZ in PBM is a new thing in learning and has the advantage for students to learn it, the appropriate method of use is through the use of learning modules. Through this module, users can help students to identify and solve problems in PBM by using TRIZ so problems can be resolved more systematically. According to Bahaman (2014), the module is also complementary to the curriculum that guides students as reference material for teaching and learning.

\section{PROBLEM STATEMENT}

In previous study, Hasliza (2002) found that most graduates were less likely to get a job because they did not have the skills to solve the problem Graduates cannot apply what they have learned in class to real-world work [5]. Their skills are only on a theoretical basis but are less capable of adjusting when in the realm of work. The unemployment problem is commonly caused by lecturers are still using a traditional learning approach that discourages students from thinking critically in problem-solving Harison's learning (2008). The findings show that lecturers lack the proper methods and to convey knowledge to students about learning that can improve their skills in 
identifying and solving the given problems. The weak students have exceptional skills in identifying problems and solving problems in PBM assignments provided by lecturers. The effect is, therefore, less motivated in the student. Besides, fewer students are given the right and systematic steps to also analyze the information to identify the root cause of the problem and solve the problem more systematically. This is because students have fewer resources to guide them to identify and solve problems. Therefore, this study was aimed to develop a problem-solving learning module in PBM by using TRIZ. The following are the research questions that support the purpose of this study; (i) is the format design suitable for the theory of integration of inventive problem-solving theory in problem-based learning?, (ii) is the content appropriate to the theory of integrating the theory of inventive problem-solving in problem-based learning accordingly?, and (iii) is the module integrating the theory of possible?

\section{METHODOLOGY}

According to Ref [6], survey study is one of the data collection approaches that can directly performed to obtain the information. The primary purpose of the survey method was to find the answer. In this study, a questionnaire was distributed to obtain the information A descriptive analysis was conducted to analyze the survey questionnaire... A total of 15 students and five lectures were selected as the respondents from Faculty Technical and Vocational Education, FPTV.

\section{A. Instrument}

Two types of instruments were used to collect data which feedback forms given to lecturers and students. The feedback instrument given to students and lecturers were adopted from by Ref [7] and UTHM book manuscript evaluation forms [5].

The validation form was given to the selected students and lecturers aimed to determine the suitability of the module design and content modules. Besides, this feedback form is also available for information on the usability of the TRIZ integration module in PBM. The number of items for student feedback form and lecturer varies.

According to Ref [6], respondents choose the answer on the item whether to agree or disagree with the use of this even number scale despite being hesitant and uncertain about the statements are given in the feedback form. In this context of study, Likert scale with ranging from 1(strongly disagree) - 4 (strongly agree) was used.

\section{B. Students}

A survey questionniare prepared students consist of four main sections; . The questionnaire was designed in Bahasa Melayu. Students were asked to answer each given item based on even numbered Likert Scale. Table 1 shows the items for each sections.

Table 1 Part of the student feedback form

\begin{tabular}{|l|c|c|c|}
\hline \multicolumn{1}{|c|}{ Dection } & Number of items for students & Number of items for lecturer \\
\hline Section A Respondent's demographic & 3 & 3 \\
\hline Section B Format design suitability for TRIZ integration module in PBM & 11 & 5 \\
\hline Section C The suitability of TRIZ integration module content in PBM & 13 & 14 \\
\hline Section D Usability of TRIZ integration module in PBM & 7 & 6 \\
\hline
\end{tabular}
inventive problem-solving in problem-based learning

\section{Lecturers}

A survey questionnaire prepared for lecturer is also consist of four main sections and designed in Bahasa Melayu. The lecturer were asked to the questionnaire with after go throught the module. Table 2 shows the total items prepared for each sections.

Table 2 Part of the lecturer feedback form

\begin{tabular}{|l|l|c|}
\hline Section & Details & Number of items \\
\hline Section A & Respondent's demographic & 3 \\
\hline Section B & Format design suitability for TRIZ integration module in PBM & 5 \\
\hline Section C & The suitability of TRIZ integration module content in PBM & 14 \\
\hline Section D & Usability of TRIZ integration module in PBM & 6 \\
\hline
\end{tabular}

\section{MODULE DESIGN}

The development process of the module was based on the Model ASSURE Generally, the ASSURE model consisted of six phased of process, , however, in this current study, only four phases was adopted. The next two phases will be discussed in the following subsequent publication.. In the first of analysis phase, learning objectives, was analyzed.Each phase of the ASSURE model for the researcher to produce the module is to analyze the development of the module, the phase of the learning objective, the method selection phase and the material source and module development phase. In the third phase of selecting methods, media and materials modified to source selection and designing modules. In the fourth phase, using media and materials was modified to module development. Each phase stated is all-encompassing, including the objectives of module, contents, order and materials used for the development of the module.

\section{RESULT AND DISCUSSION}

In this section, frequency and percentage of disagree and agree responses were recorded by using Microsoft Excel 2016 software.. There are three sections of validation; (i) Design suitability, (ii) Contents, and (iii) Usability of TRIZ

\section{A. Format design suitability for TRIZ Integration module in PBM}

Table 3 shows an analysis of the learning module format for lecturers. Based on the findings of the lecturers' feedback, it has been shown that $100 \%$ of the lecturers agree on the suitability of this module format.

Table 3: Formatting finding by lecturers

\begin{tabular}{|c|c|c|c|c|c|}
\hline \multirow{2}{*}{\multicolumn{2}{|c|}{ Items }} & \multicolumn{2}{|c|}{ Disagree } & \multicolumn{2}{|c|}{ Agree } \\
\hline & & (F) & (\%) & (F) & (\%) \\
\hline & All units have explanations of logical steps in every learning & 0 & 0 & 5 & 100 \\
\hline & Each learning activity is divided into small steps. & 0 & 0 & 5 & 100 \\
\hline & All visual elements have been integrated into every learning. & 0 & 0 & 5 & 100 \\
\hline 4 & All units form steps are organized according to each learning unit & 0 & 0 & 5 & 100 \\
\hline \multirow[t]{2}{*}{5} & Continuity of learning has been identified with the connectivity of each section. & 0 & 0 & 5 & 100 \\
\hline & TOTAL AVERAGE & 0 & $\mathbf{0}$ & 5 & 100 \\
\hline
\end{tabular}

Table 4 shows the analysis of learning module format for students. The findings for student feedback have shown that $98.17 \%$ of students agree on the suitability of this module format. However, there are $6.7 \%$ students who disagree with that interesting page 
design, tables in easy-to-read modules and writing in easy-to-read modules.

Table 4: Formatting findings by students

\begin{tabular}{|c|c|c|c|c|}
\hline \multirow{2}{*}{ Items } & \multicolumn{2}{|c|}{ Disagree } & \multicolumn{2}{|c|}{ Agree } \\
\hline & (F) & $(\%)$ & (F) & $(\%)$ \\
\hline 1 Easy to carry module size. & 0 & 0 & 15 & 100 \\
\hline 2 Attractive module page design. & 1 & 6.7 & 14 & 93.3 \\
\hline 3 The articles in the modules are easy to read. & 1 & 6.7 & 14 & 93.3 \\
\hline 4 The number of diagrams in the module is sufficient. & 0 & 0 & 15 & 100 \\
\hline 5 The diagram in the module is placed in the appropriate place to refer. & 0 & 0 & 15 & 100 \\
\hline 6 The photos in the module are placed in the appropriate place to refer. & 0 & 0 & 15 & 100 \\
\hline 7 The table in the easy-to-read module. & 1 & 6.7 & 14 & 93.3 \\
\hline 8 The composition of the text in the module is easy to follow. & 0 & 0 & 15 & 100 \\
\hline 9 Instructions in the module are clear. & 0 & 0 & 15 & 100 \\
\hline 10 Correct use of spelling. & 0 & 0 & 15 & 100 \\
\hline 11 Clear use of punctuation. & 0 & 0 & 15 & 100 \\
\hline TOTAL AVERAGE & 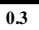 & 1.83 & 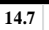 & (98.17 \\
\hline
\end{tabular}

Based on the findings of the analysis of lecturers and students agree that the format in the module is likely appropriate. The reason contribute to the positive finding is because each module was designed with graphics, interactive visuals that offers interesting learning. All units from the learning steps of each unit and the continuity of learning can also be identified with the connectors in each part of the learning as the layout is well organized and systematically. Indirectly increase and disseminate knowledge widely and systematically and effectively to students and teachers [8].

The size of the developed module is easy to carry as it is B5 size and flexible to be carried anywhere. The use of pictures and also graphics are placed in the right place with the learning content to attract students. The instructions given in the module are clear to facilitate the student to perform strengthening exercises as well as games that can relieve the student's mind. It is supported by Siddiqi (2002) which says that useful module features are complete content, taking into account individual differences, objective statements, self-referrals, using various media methods and materials and exciting and clear graphic presentations.

Besides, composing text in the module makes respondents easy to follow every learning in the module. Correct use of spelling and precise punctuation can help respondents to understand the contents of the module. Systematic compilation of learning content can help students to learn more easily and quickly. This is supported by [9] which stated that the achievement of a student can be improved if the modules are designed that meet the students' needs.

However, respondents disagree with the design of the module pages. This is because researchers are using the module design designated by UTHM Publisher. Besides, respondents also disagree that writing in the modules is easy to read. Researchers admit that there are some blurring writings because the writing is in the picture. This is because the pixel level in the image is low, causing the writing to be challenging to read.

\section{B. Content suitability for TRIZ Integration module in PBM}

Table 5 shows the lecturer feedback analysis for the suitability of the contents of the module. Based on the findings of the lecturer feedback analysis, 97.14\% have agreed upon the suitability of the content of this module. However, there are $20 \%$ of lecturers disagree with the requirement that this module meets a clear layout and layout is well organized.

Table 5: Content Module Analysis by Lecturers

\begin{tabular}{|l|c|c|c|c|}
\hline \multirow{2}{*}{ Item } & \multicolumn{2}{|c|}{ Disagree } & \multicolumn{2}{|c|}{ Agree } \\
\cline { 2 - 5 } & F & $\%$ & F & $\%$ \\
\hline 1 This module meets the obvious requirements & 1 & 20 & 4 & 80 \\
\hline 2 The purpose of the module has been explained to all users. & 0 & 0 & 5 & 100 \\
\hline 3 The introduction of this module gives a clear picture of the scope. & 0 & 0 & 5 & 100 \\
\hline 4 The general goal is clearly related to the purpose of the module. & 0 & 0 & 5 & 100 \\
\hline 5 All objectives tend to achieve the objectives of the module clearly. & 0 & 0 & 5 & 100 \\
\hline 6 All module contents are directly related to the objective & 0 & 0 & 5 & 100 \\
\hline 7 The contents of the module have been arranged logically in order of learning. & 0 & 0 & 5 & 100 \\
\hline 8 The whole of each module unit is divided by category clearly. & 0 & 0 & 5 & 100 \\
\hline 9 All the activities is related to the module content & 0 & 0 & 5 & 100 \\
\hline 10 All instructions are clear and understandable. & 0 & 0 & 5 & 100 \\
\hline 11 All directions are easy to follow. & 0 & 0 & 5 & 100 \\
\hline 12 Layout (layout) of the page is well organized. & 1 & 20 & 4 & 80 \\
\hline 13 Layout (layout) of the page causes interesting modules. & 0 & 0 & 5 & 100 \\
\hline 14 Layout (page layout) is easy to learn. & 0 & 0 & 5 & 100 \\
\hline TOTAL AVERAGE & 0.14 & 2.86 & 4.86 & 97.14 \\
\hline \hline
\end{tabular}

Table 6 shows the student feedback feedback on the suitability of the content for the TRIZ Integration module in PBM. The findings of the student feedback analysis of $91.8 \%$ of students agree with the suitability of the module. However, there are three students $(13.3 \%)$ who do not agree with the steps shown, understand the contents of the module and do all the things directed in the module.

Table 6: Content Module Analysis by Students

\begin{tabular}{|c|c|c|c|c|c|}
\hline \multirow{2}{*}{\multicolumn{2}{|c|}{ Item }} & \multirow{2}{*}{$\begin{array}{c}\text { Frequency } \\
(\mathrm{F})\end{array}$} & \multicolumn{2}{|c|}{ Percentage Frequency } & \multirow{2}{*}{$\begin{array}{c}\text { Percentage } \\
(\%)\end{array}$} \\
\hline & & & (\%) & (F) & \\
\hline 1 & I understand the objective of the module clearly. & 0 & 0 & 15 & 100 \\
\hline 2 & I'm easy to understand the steps I have shown. & 2 & 13.3 & 13 & 86.7 \\
\hline 3 & I can understand the contents of the module. & 2 & 13.3 & 13 & 86.7 \\
\hline 4 & Guide in interesting modules. & 1 & 6.7 & 14 & 93.3 \\
\hline 5 & I can do all the things pointed out in the module. & 2 & 13.3 & 13 & 86.67 \\
\hline 6 & Idea in interesting modules. & 0 & 0 & 15 & 100 \\
\hline 7 & Words used in modules are easy to understand. & 1 & 6.7 & 14 & 93.3 \\
\hline 8 & The writing style of the module is appropriate. & 3 & 20 & 12 & 80 \\
\hline 9 & I understand all the texts in the module. & 0 & 0 & 15 & 100 \\
\hline & his module makes it easier for me to leam. & 1 & 6.7 & 14 & 93.3 \\
\hline 11 & I enjoyed studying the modules. & 0 & 0 & 15 & 100 \\
\hline 12 & The grammar used is easy to unders tand. & 3 & 20 & 12 & 80 \\
\hline 13 & The accuracy of the terms used is appropriate. & 1 & 6.7 & 14 & 93.3 \\
\hline & Total average & 1.2 & 8.2 & 13.8 & 91.8 \\
\hline
\end{tabular}

Based on the findings of the analysis of lecturers and students, it is agreed that the content in the module is appropriate. This is because, researchers have developed modules based on the module production requirements by UTHM Publishers who have three parts, the first part, the text and the end. Therefore, the module page layout is more systematic and easy to learn. Indirectly, the objectives stated in the module can be achieved.

As a result of the student feedback findings, all students understand the module's objectives clearly. Objective determination is an essential element that needs to be stated in each module. The stated objectives should be clear and achievable. According to Ref

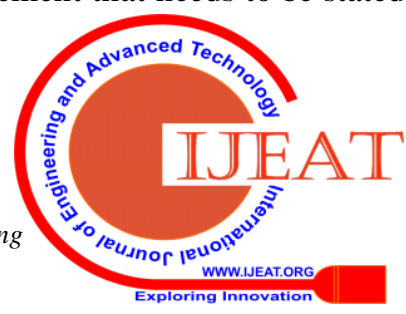


[9], objectives need to be designed based on the targeted user for the module.. Besides, respondents agreed that the ideas in this module were interesting. It is reaffirmed by Reid (2002), each individual needs to think creatively to gain a brilliant idea.

The colours used in the module was harmonious colours. Besides, researchers place an angle of info, motivational words, mind relax games and QR Code on the module to help sample to get additional information. According to S. Nasution (2003) explained that the definition of the module is a complete unit consisting of a range of student activities aimed at helping students learn more clearly and accurately.

However, some respondents argue that the words and terms used in this modules was difficult to be understand. Some terms and words used in this module was 'engineering term' which respondent will not familiar with that. This is supported by Ref[10], where new knowledge takes a long time to be implemented primarily at an individual level. Therefore, the respondents did not understand the contents of the module and could not do the subjects in the module.

\section{Usability of TRIZ Integration module in PBM}

Table 7 shows an analysis of the usability of learning modules for lecturers' perspectives. Based on the findings, All the lecturers agreed that the usability TRIZ Integration module in PBM was appropriate to the targeted users

Table 7: Module's Usability Results from Lecturers

\begin{tabular}{|c|c|c|c|c|c|}
\hline \multirow[b]{2}{*}{ No } & \multirow{2}{*}{ Item } & \multicolumn{2}{|c|}{ Disagree } & \multicolumn{2}{|c|}{ Agree } \\
\hline & & (F) & (\%) & $(\mathrm{F})$ & $(\%)$ \\
\hline 1 & All learning activities encourage active engagement and feedback. & 0 & 0 & 5 & 100 \\
\hline 2 & Diagrams, tables, charts and other graphs are used to provide clear explanations. & 0 & 0 & 5 & 100 \\
\hline 3 & The strengthening exercises available at each learning unit are appropriate. & 0 & 0 & 5 & 100 \\
\hline 4 & Overall, this module can motivate students. & 0 & 0 & 5 & 100 \\
\hline 5 & High-level thinking skills can be well integrated in the module. & 0 & 0 & 5 & 100 \\
\hline 6 & All aspects of the module can be used as a source of success for learning. & 0 & 0 & 5 & 100 \\
\hline & Total avrage & 0 & 0 & 5 & 100 \\
\hline
\end{tabular}

Table 8 shows the result of usability from students' perspective. The findings of the findings show that $96.2 \%$ of students have agreed upon the usability of the module developed. However, there are two students with a $13.3 \%$ disagreement that this module can be used throughout the teaching and learning process in the classroom and can help to complete the PBM assignments provided by the lecturers.

Table 8: Module's Usability Results from Students

\begin{tabular}{|c|l|c|c|c|c|}
\hline \multirow{2}{*}{ No } & \multicolumn{1}{|c|}{ Iisagree } & \multicolumn{3}{c|}{ Agree } \\
& & (F) & (\%) & (F) & (\%) \\
\hline 1 & $\begin{array}{l}\text { This module can be used as the main reference to solve PBM problem by } \\
\text { using TRIZ. }\end{array}$ & 0 & 0 & 15 & 100 \\
\hline 2 & This module can be used by me self-learning. & 0 & 0 & 15 & 100 \\
\hline 3 & $\begin{array}{l}\text { This module can be used throughout the teaching and learning process } \\
\text { learning in the classroom. }\end{array}$ & 2 & 13.3 & 13 & 86.7 \\
\hline 4 & $\begin{array}{l}\text { The information contained in the module helps me master problem solving in } \\
\text { PBM by using TRIZ. }\end{array}$ & 0 & 0 & 15 & 100 \\
\hline 5 & This module helps me to carry out PBM assignments provided by lecturers. & 2 & 13.3 & 13 & 86.7 \\
\hline 6 & $\begin{array}{l}\text { The Glossary of this module helps me to search the meaning of a term with } \\
\text { ease. }\end{array}$ & 0 & 0 & 15 & 100 \\
\hline 7 & Index in this module helps me to search terms easily. & 0 & 0 & 15 & 100 \\
\hline & Total Average & $\mathbf{0 . 6}$ & $\mathbf{3 . 8}$ & $\mathbf{1 4 . 4}$ & $\mathbf{9 6 . 2}$ \\
\hline
\end{tabular}

Based on the analysis of the findings of the lecturers' feedback and the students found that all agreed that this module can be implement with some recommendation of improvement. This module can be the main source of reference for problem-solving in PBM by using TRIZ. This is because with this module help the student to complete the assignment given by the lecturer. This statement is supported by Shaharudin \& Fatimah (2011) which, this learning module is one of the sources of reference and guidance in the learning process of each student. Additionally, this module also has a glossary section that can help find something less incomprehensible. So with the learning of TRIZ application in PBM students and lecturers, there is no problem while using this module because the glossary section can help to understand the grammar used. This is because the module is complementary to the curriculum, which is used as a guide to students as reference material for teaching and learning [2].

The module developed helps students to use self-learning. This is because, through learning using modules, it can allow students to create their learning styles and to give students the freedom to test the understanding of each individual's knowledge [11].The use of this module is also suitable for problem-based learning because of learning materials such as this module, and students can review self-learning without the help of lecturers. Furthermore, the index can help students and lecturers find the term easily on the pages provided.

Researchers have used infographics and diagrams, so students will not getting bored to use this module to learn. This is reaffirmed by Ref [12], without a diagram, a problem would be challenging to solve. Students are happy to learn by using this module as the guides in the module can attract users. However, some students disagree that this module can not be used throughout the teaching and learning process in the classroom and does not help in carrying out PBM assignments provided by the lecturers. This is because this module is for self-study and is only used as a reference source for the user. Overall, based on the highest percentage, this module can be used for problem-solving in learning.

\section{CONCLUSION}

From the findings, studies have shown that the format, contents and usability of these modules have been accepted by lecturers and students as reference materials for them to solve the problem. This is because the researcher has obtained five validation experts in the field of PBM and TRIZ for the suitability of the module to be applicable to consumers. Therefore, the first objective of the research in developing the TRIZ Integration Module in PBM has succeeded in achieving the objectives and has answered all the questions of this study. based on the results of the findings, the researchers are of the opinion that TRIZ is a new learning that needs to be applied to students so that students are able and able to solve problems in PBM and also in the work world later. Students can also apply this TRIZ solution in their daily life when it has the basis of the solution. therefore, there are several aspects required in further studies are:

I. Prepare a picture of the real owner and does not use pictures on the internet because it hinders the process of selling the learning module later.

II. The number of samples should be increased if such a study is to be conducted.

III. Test the effectiveness of developed learning modules. 


\section{REFERENCES}

1. Othman, M., Penyelesaian Masalah Teknik dan Aplikasi. 2008, Serdang: Penerbitan Universiti Putra Malaysia.

2. Baharom, M.A., Psikologi Pendidikan Dalam PTV. 2008, Universiti Tun Hussein Onn Malaysia, UTHM.: Penerbit Universiti Tun Hussein Onn Malaysia, UTHM.

3. Rohani, A., Effect of Problem Based Learning Approach in Learning of Statistic Aong University Students. Procedia Social and Behavioral Science 2010: p. 384-392.

4. Altshuller, G., the Innovation Algorithm: TRIZ - Systematic Innovation and technical Creativity. 2007, Wordcester: Tenchnical Innovation centre, Inc.

5. Mohammad, M.Y., Vocational Pedagogy A Dimension of Vocational Learning With Workplace requirement. Journal of Technical Education and Trainning (JTET), 2012: p. 23-30.

6. Chua, Y.P., Kaedah Penyelidikan Vol. 1. 2006, Kuala Lumpur: Mc Graw Hill (Malaysia) Sdn. Bhd.

7. Yee, M.H. The Need Analysisi of Learning Higher Of Thingking Skill among technical Students. in Proc. of the 3rd International Conference on Education and Educational Psychology (ICEEPSY 2012). 2012. Turkey: Istanbul.

8. Arsat, N.A., Pembangunan Modul Basic Of Electric And Electronic 2010, Skudai: Universiti Teknikal Malaysia.

9. Mohd Noah, S., Pembinaan Modul: Bagaimana membina modul latihan dan modul akademik. 2005, Serdang: Universiti Putra Malaysia.

10. Ruggles. R., H., Kelebihan Pengetahuan Kejayaan Pasaran dari Kaca Mata 14 Tokoh Wawasan. 2009, USA: Capstone US Business Book Network.

11. Haspiah, B., Pembangunan Dan Penilaian Modul Pengajaran Dan Pembelajaran Menggunakan Kalkulator Grafik Dalam Pembelajaran Persamaan Kuadratik, 2006, Universiti Teknologi Malaysia: Skudai, Malaysia.

12. Beckmann, S., Solving Algebra and Other Story Problems with SImple Diagrams. A Method Demonstrayed in Grade 4-6 Texts Used in SIngapore. The Mathematic Educator. , 2004. 14(1): p. 42-46.

\section{AUTHORS PROFILE}

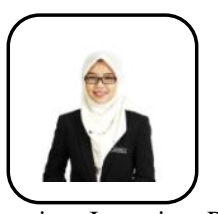

Che Wan Husna Syahirah Bt Che Wan Razak, is a master student of technical and vocational education, Universiti Tun Hussein Onn Malaysia (UTHM). She graduated degree in Bachelor of Vocational Education (Building Construction) from UTHM in 2018. She currently doing her research in Problem Based Learning using Inventive Problem Solving Theory (TRIZ). The author is also a practitioner of TRIZ (Inventive Problem Solving Theory).

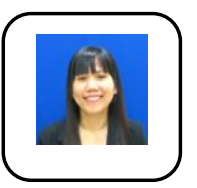

Dr Yee Mei Heong is the senior lecturer for the Department of Engineering Education (JPK) at the Faculty of Technical and Vocational Education of Universiti Tun Husseion Onn of Malaysia (UTHM). She graduated with a Bachelor of Technology in Education (Civil Engineering) with honors at the Universiti Teknologi Malaysia in 2002, and then went on to pursue a Master of Technical and Vocational Education at the Universiti Teknologi Malaysia in 2005. She received a master's degree in Doctor of Education Philosophy Engineering and Vocational at Universiti Tun Hussein Onn Malaysia in 2015. She has teaching experience as a Graduate Educational Services Officer at Maktab Rendah Sains MARA Gerik, Perak for 3 years and a senior lecturer at UTHM for 10 years. She is currently the chair of the Doctor of Education Philosophy Program since 2014. She also served as chair of the brick lab in 2014-2016. Her academic expertise includes teaching and learning problem solving skills. She has published over 90 articles / journals / teaching modules / books / book chapters in his area of expertise.

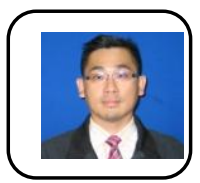

Tee Tze Kiong was born in Melaka, Malaysia on the $25^{\text {th }}$ of April, 1979. He obtained his first degree in bachelor of technology with education (civil engineering) at the Faculty of Education, Universiti Teknologi Malaysia, Skudai, Johor, Malaysia in 2002. In 2003, he completed his Master's degree in technical and vocational education at University Teknologi Malaysia, Skudai, Johor, Malaysia in. At the year 2013, he obtained his Ph.D. in technical and vocational education at Universiti Tun Hussein Onn Malaysia, Batu Pahat, Johor, Malaysia. His Ph.D. research focuses on higher order thinking skills and Buzan Mind Mapping. His working experiences include; secondary school teacher, subject matter expert, e-tutor, e-grader, proctor for final examination at Open University Malaysia, industrial practicum supervisor, undergraduate project, master and Ph.D. thesis supervisor, undergraduate, master and Ph.D. examiner, subject matter expert and examiner in Technical and Vocational Education courses, professional consultant for Multiple Intelligent Tests and Learning Styles Inventory, instrument construction workshop, senior lecturer and head of department of Engineering Technology at Sultan Idris Education University. Now, he is a lecturer in the Department of Professional Education, Faculty of Technical and Vocational Education, at Universiti Tun Hussein Onn Malaysia. (Email: tktee@uthm.edu.my). Current and previous research interests are thinking skills, thinking tools, self-instructional modular approach, learning styles and inventive problem-solving skills. Dr. Tee is a member of Universiti Teknologi Malaysia Alumni, Universiti Tun Hussein Onn Malaysia Alumni, Malaysia Technical and Vocational Education Association and TRIZ level I instructor.

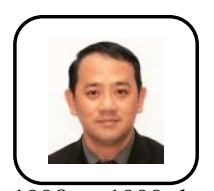

Prof. Madya Ts. Dr. Kok Boon Ching obtained his Bachelor's degree (Electrical Engineering), Master's degree (Electrical Engineering) and Doctor of Philosophy (Electrical Engineering) respectively in 1998, 2002 and 2009 from Universiti Teknologi Malaysia (UTM). From 1998 to 1999, he served in the Engineering Department, Likom Technology Sdn. Bhd., As a Product Engineer. He also served at TNB Research Sdn. Bhd. (TNBR) as a researcher from 2001 to 2003. He has been in the field of higher education since 2004 at the Department of Electrical Engineering (JEK), Faculty of Electrical and Electronic Engineering (FKEE), University of Tun Hussein Onn Malaysia (UTHM). He currently serves as an Associate Professor at UTHM. His areas of expertise include electrical power systems, renewable energy, energy harvesting systems, Continuous High Voltage (HVDC) and revenue-based education (OBE). He has been providing OBE related advisory services to the Vocational College (KV), National Youth Skills Institute (IKBN) and Southern University College since 2015. He has published more than 70 articles / journals / teaching modules / book chapters in his area of expertise. He has been a registered member of the Board of Engineers of Malaysia (BEM) since 1998. Currently, he is also a member of the IEEE international professional body and a graduate of the Malaysian Institute of Engineers (IEM).

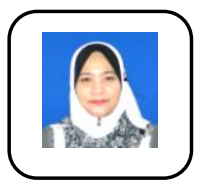

Prof. Madya Ts. Dr. Mimi Mohaffyza Binti Mohamad the senior lecturer for the Department of Engineering Education (JPK) at the Faculty of Technical and Vocational Education of Universiti Tun Husseion Onn of Malaysia (UTHM). She graduated with a Bachelor of Technology in Education with honors at the Universit Teknologi Malaysia in 2003, and then went on to pursue a Master of Technical and Vocational Education at the Universiti Teknologi Malaysia in 2006. She received a master's degree in Doctor of Education Philosophy Engineering and Vocational at Universiti Teknologi Malaysia in 2012. She is currently Head of department of Training and Industrial Training, Faculty of Technical and Vocational, UTHM. Her academic expertise includes teaching and learning problem solving skills. She has published over 90 articles / journals / teaching modules / books / book chapters in his area of expertise. 